\title{
ANALISIS PERBANDINGAN ANTARA FONDASI TIANG PANCANG BAJA $H$-PILES DAN FONDASI TIANG PANCANG BETON PERSEGI PRESTRESSED
}

\author{
Windy Widyarti Astari ${ }^{1}$ dan Alfred Jonathan Susilo ${ }^{2}$ \\ ${ }^{1}$ Program Studi Sarjana Teknik Sipil, Universitas Tarumanagara, Jl. Letjen S. Parman No.1 Jakarta \\ Email: windywidyarti7@gmail.com \\ ${ }^{2}$ Program Studi Sarjana Teknik Sipil, Universitas Tarumanagara, Jl. Letjen S. Parman No.1 Jakarta \\ Email: alfredsusilo@gmail.com
}

\begin{abstract}
ABSTRAK
Sebagai struktur yang menopang beban struktur bangunan di atasnya, fondasi tiang pancang adalah salah satu jenis fondasi dalam yang sering digunakan dalam konstruksi bangunan. Berbeda dengan di negara lain seperti di Amerika Serikat, di Indonesia tiang pancang yang paling sering digunakan adalah tiang pancang beton dibandingkan tiang pancang baja maupun kayu. Untuk memperoleh hasil yang efisien, pemilihan jenis fondasi yang tepat merupakan hal yang sangat penting untuk dilakukan. Pada skripsi ini akan dilakukan analisis apakah fondasi tiang pancang beton persegi prestressed lebih banyak digunakan di Indonesia karena memang lebih optimal untuk diterapkan dibandingkan dengan fondasi tiang pancang baja H-Piles. Analisis akan dilakukan dengan cara melakukan perhitungan kapasitas tekan, kapasitas tarik dan penurunan fondasi tiang pancang baja H-Piles dan tiang pancang beton persegi prestressed apabila kedua tiang memiliki dimensi panjang dan lebar yang sama yang dikondisikan berada pada tanah yang sama. Analisis perhitungan terhadap kapasitas tekan, kapasitas tarik dan penurunan tiang akan dilakukan dengan perhitungan secara manual dan di cek dengan menggunakan software komputer. Hasil analisis pondasi tiang pancang baja H-Piles dan tiang pancang beton persegi prestressed tersebut kemudian akan dibandingkan dan dihitung selisih biaya material kedua tiang sebagai pertimbangan dalam pemilihan jenis fondasi tiang pancang hingga dapat disimpulkan jenis fondasi yang lebih optimal untuk digunakan pada tanah yang di analisis.
\end{abstract}

Kata kunci: kapasitas tiang, tiang baja H-Piles, tiang beton persegi prestressed, penurunan tiang

\section{PENDAHULUAN}

"Fondasi ialah bagian dari suatu sistem rekayasa yang meneruskan beban yang ditopang oleh fondasi dan beratnya sendiri kepada dan ke dalam tanah dan batuan yang terletak di bawahnya" (Bowles, 1997). Coduto, Kitch dan Yeung (2016) mengklasifikasikan fondasi kedalam 2 kategori, yaitu fondasi dangkal (shallow foundations) dan fondasi dalam (deep foundations). Pada karya tulis ini, jenis fondasi yang akan dibahas adalah fondasi dalam yaitu tiang pancang (driven piles). Tiang pancang dapat terbuat dari kayu, beton, baja dan komposit (Deep Foundation Research Institute, 2013). Menurut Coduto, Kitch dan Yeung (2016), terdapat banyak faktor yang perlu dipertimbangkan saat memilih material tiang fondasi, yaitu; beban yang bekerja, diameter yang dibutuhkan, panjang tiang yang dibutuhkan, ketersediaan tipe tiang pada daerah setempat, ketahanan tiang di lingkungan tertentu dan ketahanan tiang terhadap pemberian beban dinamik. Namun perlu diingat juga bahwa biaya (cost) merupakan salah satu unsur yang sangat penting dalam proyek konstruksi sehingga selain mempertimbangkan faktor-faktor di atas, fondasi juga perlu di desain dengan baik agar efisien dan tidak over design untuk menghemat biaya konstruksi. Dengan pertimbangan di atas, pada skripsi ini akan dilakukan analisis perbandingan kapasitas tekan, kapasitas tarik, penurunan dan harga material kedua jenis fondasi tiang pancang dengan material berbeda yaitu fondasi tiang pancang baja $\mathrm{H}$-Piles dan fondasi tiang pancang beton persegi prestressed dengan dimensi panjang dan lebar yang sama yaitu $400 \mathrm{~mm}$ untuk memperoleh jenis fondasi yang lebih efisien untuk diterapkan.

\section{Batasan Masalah}

- Fondasi tiang pancang baja H-Piles 400x400x13x21 mm yang digunakan sesuai dengan spesifikasi tiang Tiong Woon Corporation Holding Ltd, sedangkan fondasi tiang pancang beton persegi prestressed $400 \mathrm{x} 400 \mathrm{~mm}$ yang digunakan sesuai dengan spesifikasi tiang PT Adhi Persada Beton.

- Analisis kapasitas tekan, kapasitas tarik dan penurunan primer menggunakan perhitungan secara manual dan di cek dengan software komputer tanpa memperhitungkan korosi, sambungan dan pelapukan terhadap kedua jenis tiang fondasi tunggal free-head dengan beban aksial saja dan dikondisikan berada pada tanah dominan lanau yang sama dengan data tanah yang diperoleh dari salah satu perusahaan spesialis penyelidikan tanah.

- Analisis biaya dilakukan terhadap harga material tidak termasuk biaya instalasi tiang. 


\section{Tujuan Penelitian}

Tujuan penelitian ini adalah untuk mengetahui jenis fondasi yang lebih optimal untuk diterapkan pada tanah yang di analisis dengan menghitung perbandingan kapasitas tekan, kapasitas tarik, penurunan dan besar harga material hingga diperoleh selisih harga material dan persen penghematan yang dapat dilakukan terhadap penggunaan fondasi tiang pancang baja $H$-Piles dan fondasi tiang pancang beton persegi prestressed apabila kedua tiang dikondisikan berada pada tanah yang sama dan memiliki dimensi panjang dan lebar yang sama yaitu 400x400 mm dengan menggunakan perhitungan secara manual dan di cek menggunakan software komputer.

\section{TINJAUAN PUSTAKA}

Menurut Coduto, Kitch dan Yeung (2016), fondasi dalam yang tertua adalah tiang pancang. Sardjono (1988) mengemukakan bahwa tiang pancang dipergunakan sebagai fondasi suatu bangunan apabila tanah dasar di bawah bangunan tersebut tidak mempunyai daya dukung (bearing capacity) yang cukup untuk memikul berat bangunan dan bebannya, atau apabila tanah keras yang mempunyai daya dukung yang cukup untuk memikul beban ini letaknya sangat dalam.

Sebagai fondasi tiang, kebanyakan penampang tiang pancang baja berbentuk profil H. Karena terbuat dari baja, maka kekuatan tiang ini sendiri sangat besar sehingga dalam pemancangan tidak menimbulkan bahaya patah seperti pada tiang pancang beton prestressed. Menurut Salgado (2008), pada fondasi H-Piles perlu diperhitungkan adanya keadaan plug dan unplugged dimana plug adalah penyumbatan dengan tanah pada tiang. H-Piles yang dibebani secara statik dan berada di pasir tidak akan membentuk plug seperti pada gambar 1(a). Saat H-Piles di instalasikan pada tanah lempung yang lunak (soft clay), akan terbentuk plug diantara flanges saat H-Piles diberi beban static seperti pada gambar 1(b). Menurut Tomlinson (1987) pada Salgado (2008), plug tanah dengan panjang tertentu pada pada bagian atas tiang dapat retak dan terlepas dari tiang di tanah lempung keras (stiff clay). Ini akan menyebabkan tanah yang volumenya relatif longgar akan bertambah diantara flanges sehingga tanah ini tidak akan berkontribusi dalam tahanan selimut tiang. Tanah yang digunakan dalam analisis perhitungan fondasi pada karya ilmiah ini merupakan tanah lempung keras (stiff clay), oleh karena itu berdasarkan pertimbangan plugged dan unplugged diatas maka pada luasan penampang untuk perhitungan tahanan ujung dan tahanan selimut tiang fondasi dihitung seperti pada gambar 1(c).

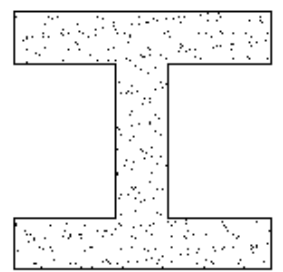

(a)

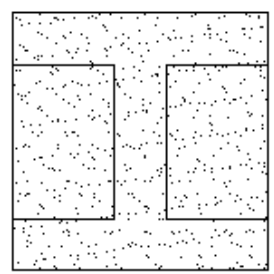

(b)

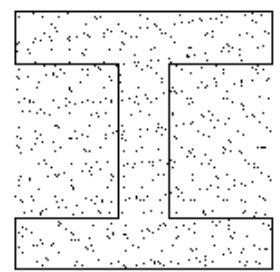

(c)

Gambar 1. Luas Bidang Perhitungan Tahanan Ujung dan Selimut Tiang untuk H-Piles

Catatan: gambar 1(a) Pasir, (b) Lempung lunak dan (c) Lempung keras. Garis tebal menandakan luasan untuk perhitungan tahanan selimut; Arsiran menandakan luasan untuk perhitungan tahanan ujung

Untuk memperoleh kapasitas izin tiang fondasi, diperlukan faktor keamanan (SF) untuk mereduksi kapasitas tiang. Berdasarkan SNI Persyaratan Perancangan Geoteknik (2017), nilai faktor keamanan untuk kapasitas tekan izin fondasi besarnya minimum 3 untuk fondasi dangkal atau minimum 2.5 untuk fondasi dalam.

\section{METODOLOGI PENELITIAN}

Dalam penelitian ini dilakukan beberapa tahapan yang dapat diuraikan sebagai berikut:

Tahapan pertama adalah melakukan pengumpulan data berupa data tanah (hasil tes boring log dan hasil uji laboratorium), data tiang (spesifikasi tiang yang tersedia di pasaran) dan buku referensi maupun jurnal yang terkait.

Tahapan kedua adalah melakukan analisis perhitungan kapasitas tekan, kapasitas tarik dan penurunan fondasi tiang pancang baja $H$-Piles dan fondasi tiang pancang beton persegi prestressed dengan perhitungan manual.

Tahapan ketiga adalah melakukan pengecekan hasil perhitungan manual dengan menggunakan software komputer.

Tahapan keempat adalah melakukan analisis terhadap hasil perhitungan kapasitas dan penurunan tiang.

Tahapan kelima adalah menghitung harga material yang dibutuhkan kedua jenis tiang dan menarik kesimpulan berdasarkan hasil analisis yang telah dilakukan. 


\section{ANALISIS DAN PEMBAHASAN}

Analisis dilakukan berdasarkan data tanah yang diperoleh dari salah satu perusahaan spesialis penyelidikan tanah dengan lapisan tanah seperti pada tabel 1 .

Tabel 1. Lapisan tanah

\begin{tabular}{|c|c|c|c|c|c|c|c|}
\hline $\begin{array}{c}\text { Ked. } \\
(\mathrm{m})\end{array}$ & Deskripsi Tanah & Sym. & N-SPT & $\begin{array}{c}\text { Ked. } \\
(\mathrm{m})\end{array}$ & Deskripsi Tanah & Sym. & $\begin{array}{l}\text { N- } \\
\text { SPT }\end{array}$ \\
\hline 0 & \multirow{6}{*}{$\begin{array}{c}\text { LANAU BERLEMPUNG } \\
\text { Abu-abu, lembab, } \\
\text { kekakuan sedang, } \\
\text { plastisitas tinggi }\end{array}$} & \multirow{6}{*}{ MH } & \multirow{6}{*}{8} & 16 & \multirow{5}{*}{$\begin{array}{c}\text { PASIR } \\
\text { BERLEMPUNG } \\
\text { Hitam, lembab, lepas, } \\
\text { gradasi rendah }\end{array}$} & \multirow{5}{*}{ SP } & \multirow{2}{*}{8} \\
\hline 1 & & & & 17 & & & \\
\hline 2 & & & & 18 & & & \multirow{2}{*}{7} \\
\hline 3 & & & & 19 & & & \\
\hline 4 & & & & 20 & & & \multirow{2}{*}{11} \\
\hline 5 & & & & 21 & \multirow{5}{*}{$\begin{array}{c}\text { LANAU } \\
\text { BERLEMPUNG } \\
\text { Cokelat, lembab, kaku, } \\
\text { plastisitas rendah }\end{array}$} & \multirow{5}{*}{ ML } & \\
\hline 6 & \multirow{4}{*}{$\begin{array}{l}\text { LANAU BERLEMPUNG } \\
\text { Hitam, lembab, lunak, } \\
\text { mengandung banyak } \\
\text { material organik, } \\
\text { plastisitas tinggi }\end{array}$} & \multirow{4}{*}{$\mathrm{MH}$} & \multirow[t]{2}{*}{3} & 22 & & & \\
\hline$\frac{7}{8}$ & & & & 23 & & & 9 \\
\hline 9 & & & \multirow[t]{3}{*}{4} & 24 & & & 17 \\
\hline 10 & & & & 25 & & & \\
\hline 11 & \multirow{5}{*}{$\begin{array}{c}\text { LEMPUNG } \\
\text { Hitam, lembab, kekakuan } \\
\text { sedang, mengandung } \\
\text { banyak material organik } \\
\text { dan pasir halus, plastisitas } \\
\text { rendah } \\
\end{array}$} & \multirow{5}{*}{ CL } & & 26 & \multirow{5}{*}{$\begin{array}{c}\text { LEMPUNG } \\
\text { BERLANAU } \\
\text { Abu-abu kekuningan, } \\
\text { sangat kaku, plastisitas } \\
\text { rendah }\end{array}$} & \multirow{5}{*}{$\mathrm{CL}$} & \multirow{5}{*}{20} \\
\hline 12 & & & \multirow[t]{2}{*}{7} & 27 & & & \\
\hline 13 & & & & 28 & & & \\
\hline 14 & & & 9 & 29 & & & \\
\hline 15 & & & 9 & 30 & & & \\
\hline
\end{tabular}

Nilai parameter tanah yang digunakan diperoleh dari hasil uji laboratorium dan korelasi berdasarkan data yang dimiliki. Berikut merupakan tabel parameter yang digunakan.

Tabel 2. Parameter tanah

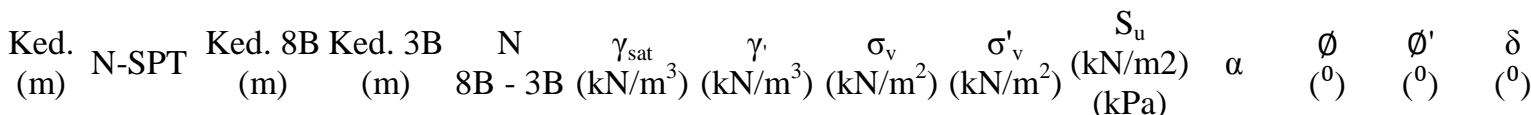

\begin{tabular}{cccccccccccccc}
\hline 0 & 8 & 0.00 & 0.00 & 8.00 & 16.50 & 16.50 & 0.00 & 0.00 & 0.00 & 0.00 & 0.00 & - & 0.00 \\
\hline 1 & 8 & 0.00 & 2.20 & 8.00 & 16.50 & 16.50 & 16.50 & 16.50 & 50.00 & 0.90 & 15.00 & - & 11.25 \\
\hline 2 & 8 & 0.00 & 3.20 & 8.00 & 16.50 & 16.50 & 33.00 & 33.00 & 50.00 & 0.90 & 15.00 & - & 11.25 \\
\hline 3 & 8 & 0.00 & 4.20 & 8.00 & 16.50 & 12.50 & 49.50 & 45.50 & 50.00 & 0.90 & 15.00 & - & 11.25 \\
\hline 4 & 8 & 0.80 & 5.20 & 7.77 & 16.50 & 6.50 & 66.00 & 52.00 & 50.00 & 0.90 & 15.00 & - & 11.25 \\
\hline 5 & 8 & 1.80 & 6.20 & 6.64 & 16.50 & 6.50 & 82.50 & 58.50 & 43.80 & 0.92 & 15.00 & - & 11.25 \\
\hline 6 & 3 & 2.80 & 7.20 & 5.50 & 14.00 & 4.00 & 96.50 & 62.50 & 37.50 & 0.95 & 2.00 & - & 1.50 \\
\hline 7 & 3 & 3.80 & 8.20 & 4.36 & 14.00 & 4.00 & 110.50 & 66.50 & 25.00 & 1.00 & 2.00 & - & 1.50 \\
\hline 8 & 4 & 4.80 & 9.20 & 3.23 & 14.00 & 4.00 & 124.50 & 70.50 & 18.80 & 1.02 & 2.00 & - & 1.50 \\
\hline 9 & 4 & 5.80 & 10.20 & 3.18 & 14.00 & 4.00 & 138.50 & 74.50 & 18.80 & 1.02 & 2.00 & - & 1.50 \\
\hline 10 & 4 & 6.80 & 11.20 & 4.09 & 14.00 & 4.00 & 152.50 & 78.50 & 25.00 & 1.00 & 2.00 & - & 1.50 \\
\hline 11 & 4 & 7.80 & 12.20 & 5.00 & 15.50 & 5.50 & 168.00 & 84.00 & 31.30 & 0.97 & 2.00 & - & 1.50 \\
\hline 12 & 7 & 8.80 & 13.20 & 5.91 & 15.50 & 5.50 & 183.50 & 89.50 & 37.50 & 0.95 & 2.00 & - & 1.50 \\
\hline 13 & 7 & 9.80 & 14.20 & 6.82 & 15.50 & 5.50 & 199.00 & 95.00 & 43.80 & 0.92 & 2.00 & - & 1.50 \\
\hline 14 & 9 & 10.80 & 15.20 & 7.05 & 15.50 & 5.50 & 214.50 & 100.50 & 43.80 & 0.92 & 2.00 & - & 1.50 \\
\hline 15 & 9 & 11.80 & 16.20 & 7.27 & 15.50 & 5.50 & 230.00 & 106.00 & 43.80 & 0.92 & 2.00 & - & 1.50 \\
\hline 16 & 8 & 12.80 & 17.20 & 7.50 & 17.00 & 7.00 & 247.00 & 113.00 & - & - & 33.00 & 32.33 & 24.75 \\
\hline 17 & 8 & 13.80 & 18.20 & 7.73 & 17.00 & 7.00 & 264.00 & 120.00 & - & - & 33.00 & 32.33 & 24.75 \\
\hline 18 & 8 & 14.80 & 19.20 & 7.95 & 17.00 & 7.00 & 281.00 & 127.00 & - & - & 33.00 & 32.33 & 24.75 \\
\hline 19 & 8 & 15.80 & 20.20 & 8.18 & 17.00 & 7.00 & 298.00 & 134.00 & - & - & 33.00 & 32.33 & 24.75 \\
\hline
\end{tabular}


Lanjutan tabel 2.

\begin{tabular}{cccccccccccccc}
\hline $\begin{array}{c}\text { Ked. } \\
(\mathrm{m})\end{array}$ & $\begin{array}{c}\mathrm{N}- \\
\mathrm{SPT}\end{array}$ & $\begin{array}{c}\text { Ked. 8B Ked. 3B } \\
(\mathrm{m})\end{array}$ & $\begin{array}{c}\mathrm{N} \\
(\mathrm{m})\end{array}$ & $\begin{array}{c}\gamma_{\mathrm{sat}} \\
8 \mathrm{~B}-3 \mathrm{~B}\end{array}$ & $\begin{array}{c}\gamma^{\prime} \\
\left(\mathrm{kN} / \mathrm{m}^{3}\right)\end{array}$ & $\begin{array}{c}\sigma_{\mathrm{v}} \\
\left(\mathrm{kN} / \mathrm{m}^{3}\right)\end{array}$ & $\begin{array}{c}\sigma_{\mathrm{v}}^{\prime} \\
\left(\mathrm{kN} / \mathrm{m}^{2}\right)\end{array}$ & $\begin{array}{c}\mathrm{S}_{\mathrm{u}} \\
\left(\mathrm{kN} / \mathrm{m}^{2}\right)\end{array}$ & $\begin{array}{c}\phi N / m 2) \\
(\mathrm{kPa})\end{array}$ & $\alpha$ & $\begin{array}{c}\phi \\
\left({ }^{0}\right)\end{array}$ & $\begin{array}{c}\phi^{\prime} \\
\left({ }^{0}\right)\end{array}$ & $\begin{array}{c}\delta \\
\left({ }^{0}\right)\end{array}$ \\
\hline 20 & 11 & 16.80 & 21.20 & 9.09 & 17.00 & 7.00 & 315.00 & 141.00 & - & - & 33.00 & 33.17 & 24.75 \\
\hline 21 & 11 & 17.80 & 22.20 & 10.00 & 17.00 & 7.00 & 332.00 & 148.00 & 34.50 & 0.96 & 17.00 & - & 12.75 \\
\hline 22 & 9 & 18.80 & 23.20 & 10.91 & 17.00 & 7.00 & 349.00 & 155.00 & 37.90 & 0.95 & 17.00 & - & 12.75 \\
\hline 23 & 9 & 19.80 & 24.20 & 11.82 & 17.00 & 7.00 & 366.00 & 162.00 & 41.40 & 0.93 & 17.00 & - & 12.75 \\
\hline 24 & 17 & 20.80 & 25.20 & 12.36 & 17.00 & 7.00 & 383.00 & 169.00 & 41.40 & 0.93 & 17.00 & - & 12.75 \\
\hline 25 & 17 & 21.80 & 26.20 & 14.18 & 17.00 & 7.00 & 400.00 & 176.00 & 48.30 & 0.91 & 17.00 & - & 12.75 \\
\hline 26 & 20 & 22.80 & 27.20 & 16.00 & 17.00 & 7.00 & 417.00 & 183.00 & 106.70 & 0.72 & 17.00 & - & 12.75 \\
\hline 27 & 20 & 23.80 & 28.20 & 17.82 & 17.00 & 7.00 & 434.00 & 190.00 & 120.00 & 0.69 & 17.00 & - & 12.75 \\
\hline 28 & 20 & 24.80 & 29.20 & 19.64 & 17.00 & 7.00 & 451.00 & 197.00 & 133.30 & 0.66 & 17.00 & - & 12.75 \\
\hline 29 & 20 & 25.80 & 30.20 & 20.00 & 17.00 & 7.00 & 468.00 & 204.00 & 133.30 & 0.66 & 17.00 & - & 12.75 \\
\hline 30 & 20 & 26.80 & 31.20 & 20.00 & 17.00 & 7.00 & 485.00 & 211.00 & 133.30 & 0.66 & 17.00 & - & 12.75 \\
\hline
\end{tabular}

Keterangan: '_' = not applicable

Analisis kapasitas tiang yang dilakukan menggunakan metode sebagai berikut; kapasitas tekan fondasi tiang menggunakan metode Bowles (1997), analisis kapasitas tarik fondasi tiang menggunakan metode Coyle dan Castello (1981) dan analisis penurunan tiang menggunakan metode semi empiris. Faktor keamanan (SF) yang digunakan adalah 3 untuk kapasitas ujung tiang dan sebesar 5 untuk kapasitas selimut tiang.

\section{Kapasitas tekan}

Kapasitas tekan izin fondasi tiang dapat dihitung dengan persamaan:

$$
\mathrm{Q}_{\text {all }}=\frac{\mathrm{Q}_{\mathrm{p}}}{\mathrm{SF}}+\frac{\mathrm{Q}_{\mathrm{s}}}{\mathrm{SF}}-\mathrm{W}_{\mathrm{p}}
$$

Dengan $\mathrm{Q}_{\text {all }}=$ kapasitas tekan izin tiang, $\mathrm{Q}_{\mathrm{p}}=$ kapasitas tekan ujung tiang, $\mathrm{Q}_{\mathrm{s}}=$ kapasitas gesek selimut tiang, $\mathrm{SF}=$ faktor keamanan (diambil 3 untuk kapasitas ujung dan 5 untuk kapasitas selimut), $\mathrm{W}_{\mathrm{p}}=$ berat tiang tertanam.

Kapasitas tekan ujung tiang dapat dihitung dengan persamaan:

$$
\mathrm{Q}_{\mathrm{p}}=\mathrm{A}_{\mathrm{p}}(40 \cdot \mathrm{N}) \frac{\mathrm{L}_{\mathrm{B}}}{\mathrm{B}} \leq \mathrm{A}_{\mathrm{p}}(380 \cdot \mathrm{N})
$$

Dengan $\mathrm{A}_{\mathrm{p}}$ = luas penampang ujung tiang, $\mathrm{N}=$ nilai $\mathrm{N}-\mathrm{SPT}$ rata-rata pada daerah $8 \mathrm{~B}$ hingga $3 \mathrm{~B}$ dari ujung fondasi, $\mathrm{L}_{\mathrm{B}}=$ panjang tiang tertanam, $\mathrm{B}=$ lebar atau diameter tiang.

Kapasitas geser selimut tiang dapat dihitung dengan persamaan:

$$
\sum_{l}^{\mathrm{n}} \mathrm{A}_{\mathrm{s}} \cdot \mathrm{f}_{\mathrm{s}}
$$

Dengan $\mathrm{A}_{\mathrm{s}}=$ luas efektif permukaan selimut tiang yaitu keliling $\mathrm{x} \Delta \mathrm{L}, \mathrm{f}_{\mathrm{s}}=$ tahanan selimut.

\section{Kapasitas tarik}

Kapasitas tarik fondasi tiang dihitung dengan menggunakan persamaan:

$$
\mathrm{T}_{\mathrm{all}}=\frac{\mathrm{Q}_{\mathrm{s}}}{5}+0.9 \cdot \mathrm{W}_{\mathrm{p}}
$$

\section{Penurunan tiang}

Penurunan fondasi tiang dihitung dengan menggunakan persamaan berikut:

$$
\mathrm{S}_{\mathrm{e}}=\mathrm{S}_{\mathrm{s}}+\mathrm{S}_{\mathrm{p}}+\mathrm{S}_{\mathrm{ps}}
$$

Dengan $S_{e}=$ penurunan elastis total fondasi tiang tunggal, $S_{\mathrm{s}}=$ penurunan akibat deformasi aksial tiang tunggal, $\mathrm{S}_{\mathrm{p}}=$ penurunan dari ujung tiang, $\mathrm{S}_{\mathrm{ps}}=$ penurunan tiang akibat beban yang dialihkan sepanjang tiang.

Penurunan akibat deformasi aksial tiang tunggal dapat dihitung dengan persamaan:

$$
\mathrm{S}_{\mathrm{s}}=\frac{\left(\mathrm{Q}_{\mathrm{p}}+\alpha \cdot \mathrm{Q}_{\mathrm{s}}\right) \cdot \mathrm{L}}{\mathrm{A}_{\mathrm{p}} \cdot \mathrm{E}_{\mathrm{p}}}
$$


Dengan $\alpha=$ koefisien yang bergantung pada distribusi gesekan selimut sepanjang fondasi tiang, $\mathrm{E}_{\mathrm{p}}=$ modulus elastisitas tiang.

Penurunan dari ujung tiang dapat dihitung dengan persamaan:

$$
\mathrm{S}_{\mathrm{p}}=\frac{\mathrm{C}_{\mathrm{p}} \cdot \mathrm{Q}_{\mathrm{p}}}{\mathrm{D} \cdot \mathrm{q}_{\mathrm{p}}}
$$

Dengan $\mathrm{C}_{\mathrm{p}}=$ koefisien empiris, $\mathrm{q}_{\mathrm{p}}=$ tahanan ujung tiang.

Penurunan akibat deformasi aksial tiang tunggal dapat dihitung dengan persamaan:

$$
\mathrm{S}_{\mathrm{ps}}=\left(\frac{\mathrm{Q}_{\mathrm{ws}}}{\mathrm{p} \cdot \mathrm{L}}\right) \cdot \frac{\mathrm{D}}{\mathrm{E}_{\mathrm{s}}} \cdot\left(1-\mathrm{v}_{\mathrm{s}}^{2}\right) \cdot \mathrm{I}_{\mathrm{ws}}
$$

Dengan $\mathrm{p}=$ keliling tiang, $\mathrm{v}_{\mathrm{s}}=$ angka Poisson tanah, $\mathrm{I}_{\mathrm{ws}}=$ faktor pengaruh, $\frac{Q_{w s}}{p \cdot L}=$ gesekan rata-rata sepanjang tiang.

\section{HASIL ANALISIS}

Berdasarkan analisis secara yang dilakukan, diperoleh kapasitas tekan izin dan kapasitas tarik izin fondasi tiang pancang baja H-Piles dan fondasi tiang pancang beton persegi prestressed seperti pada tabel 1. Pada gambar 2 dapat dilihat bahwa berdasarkan hasil analisis, pada kedalaman 30 meter kapasitas tekan izin fondasi tiang pancang beton persegi prestressed memiliki nilai $695.77 \mathrm{kN}$ yang hampir sama dengan kapasitas tekan izin fondasi tiang pancang baja $H$-Piles pada kedalaman 26 meter sebesar $704.58 \mathrm{kN}$. Sedangkan pada gambar 3 dapat dilihat bahwa berdasarkan hasil analisis, pada kedalaman 30 meter kapasitas tarik izin fondasi tiang pancang beton persegi prestressed $509.32 \mathrm{kN}$ memiliki nilai yang hampir sama dengan kapasitas tarik izin fondasi tiang pancang baja $H$ Piles pada kedalaman 27 meter sebesar $506.26 \mathrm{kN}$. Berdasarkan pertimbangan tersebut, dilakukan pemodelan analisis kapasitas tekan izin dan kapasitas tarik izin fondasi tiang pada kedalaman 26 meter dan 30 meter dengan menggunakan software komputer.

\begin{tabular}{|c|c|c|c|c|}
\hline $\begin{array}{c}\text { Ked. } \\
(\mathrm{m})\end{array}$ & $\begin{array}{c}\text { Qall } \\
\text { Beton } \\
(\mathrm{kN})\end{array}$ & $\begin{array}{c}\mathrm{Q}_{\text {all }} \\
\text { H-Piles } \\
(\mathrm{kN})\end{array}$ & $\begin{array}{c}\mathrm{T}_{\text {all }} \\
\text { Beton } \\
(\mathrm{kN})\end{array}$ & $\begin{array}{c}\mathrm{T}_{\mathrm{all}} \\
\text { H-Piles } \\
(\mathrm{kN})\end{array}$ \\
\hline 0 & 0.00 & 0.00 & 0.00 & 0.00 \\
\hline 1 & 53.23 & 62.31 & 17.86 & 22.91 \\
\hline 2 & 106.45 & 124.63 & 35.71 & 45.83 \\
\hline 3 & 159.68 & 186.94 & 53.57 & 68.74 \\
\hline 4 & 199.77 & 236.11 & 71.42 & 91.66 \\
\hline 5 & 185.86 & 230.59 & 87.84 & 112.44 \\
\hline 6 & 170.39 & 222.76 & 102.70 & 130.90 \\
\hline 7 & 151.52 & 209.88 & 114.15 & 144.32 \\
\hline 8 & 130.81 & 194.28 & 123.78 & 155.01 \\
\hline 9 & 132.22 & 200.78 & 133.40 & 165.71 \\
\hline 10 & 154.80 & 229.36 & 144.85 & 179.13 \\
\hline 11 & 179.15 & 260.55 & 158.07 & 195.16 \\
\hline 12 & 205.13 & 294.16 & 172.93 & 213.62 \\
\hline 13 & 232.68 & 330.10 & 189.35 & 234.40 \\
\hline 14 & 246.41 & 352.22 & 205.76 & 255.18 \\
\hline 15 & 260.14 & 374.34 & 222.18 & 275.96 \\
\hline
\end{tabular}

Tabel 1. Hasil analisis kapasitas tekan izin dan kapasitas tarik izin fondasi tiang dengan perhitungan secara manual

\begin{tabular}{ccccc}
\hline $\begin{array}{c}\text { Ked. } \\
(\mathrm{m})\end{array}$ & $\begin{array}{c}\mathrm{Q}_{\text {all }} \\
\text { Beton } \\
(\mathrm{kN})\end{array}$ & $\begin{array}{c}\mathrm{Q}_{\text {all }} \\
\text { H-Piles } \\
(\mathrm{kN})\end{array}$ & $\begin{array}{c}\mathrm{T}_{\text {all }} \\
\text { Beton } \\
(\mathrm{kN})\end{array}$ & $\begin{array}{c}\mathrm{T}_{\text {all }} \\
\text { H-Piles } \\
(\mathrm{kN})\end{array}$ \\
\hline 16 & 267.82 & 385.33 & 232.56 & 285.62 \\
\hline 17 & 275.94 & 396.83 & 243.37 & 295.78 \\
\hline 18 & 284.48 & 408.83 & 254.60 & 306.44 \\
\hline 19 & 293.46 & 421.33 & 266.26 & 317.60 \\
\hline 20 & 316.42 & 447.85 & 278.10 & 328.97 \\
\hline 21 & 341.63 & 480.31 & 292.18 & 346.27 \\
\hline 22 & 367.71 & 514.08 & 307.14 & 364.89 \\
\hline 23 & 394.68 & 549.16 & 322.97 & 384.80 \\
\hline 24 & 414.27 & 576.86 & 338.81 & 404.72 \\
\hline 25 & 461.30 & 632.78 & 356.28 & 427.06 \\
\hline 26 & 519.02 & 704.58 & 384.45 & 465.29 \\
\hline 27 & 578.60 & 779.14 & 414.48 & 506.26 \\
\hline 28 & 639.77 & 856.05 & 446.09 & 549.59 \\
\hline 29 & 671.45 & 903.47 & 477.70 & 592.91 \\
\hline 30 & 695.77 & 943.53 & 509.32 & 636.24 \\
\hline
\end{tabular}

Berikut merupakan hasil analisis kapasitas izin tiang dengan software komputer.

Tabel 2. Hasil analisis kapasitas tiang secara manual dan dengan software komputer

\begin{tabular}{cccc}
\hline \multirow{2}{*}{$\begin{array}{c}\text { Kedalaman } \\
(\mathrm{m})\end{array}$} & \multirow{2}{*}{ Jenis Tiang } & \multicolumn{2}{c}{ Kapasitas $(\mathrm{kN})$} \\
\cline { 3 - 4 } 26 & Bekan & Tarik \\
\hline \multirow{2}{*}{26 -Piles } & 757.81 & 435.29 \\
\cline { 2 - 4 } & Beton Persegi & 499.80 & 335.16 \\
\hline \multirow{2}{*}{30} & Baja H-Piles & 969.95 & 435.29 \\
\cline { 2 - 4 } & Beton Persegi & 581.67 & 424.98 \\
\hline
\end{tabular}


Analisis perhitungan kapasitas tiang secara manual dijadikan sebagai acuan dalam penelitian. Gambar 2 dan gambar 3 merupakan grafik kapasitas tekan izin dan kapasitas tarik izin dengan perhitungan manual.

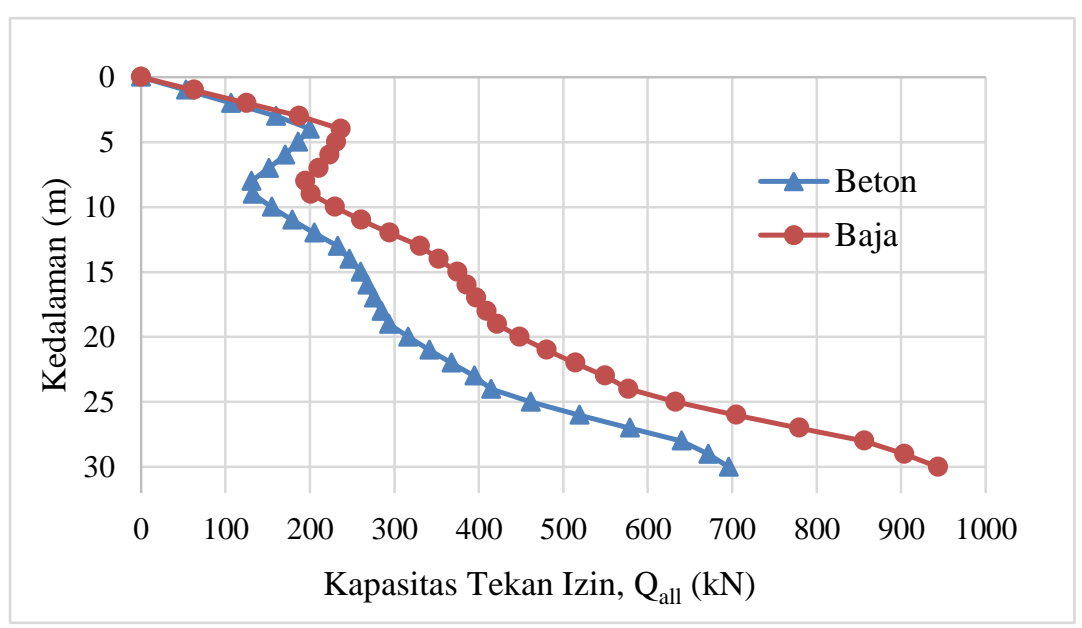

Gambar 2. Grafik kapasitas tekan izin tiang fondasi

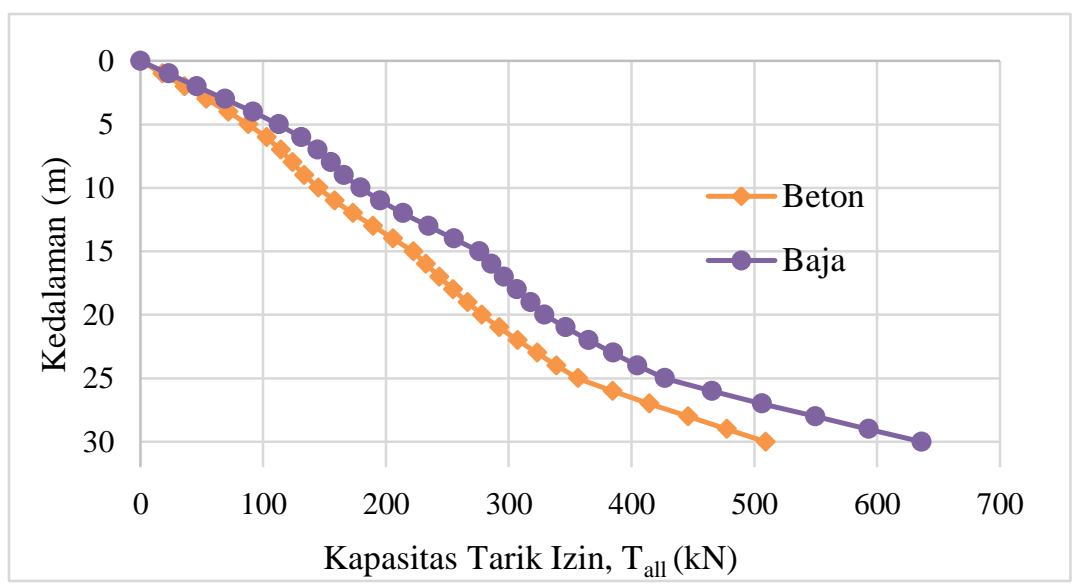

Gambar 3. Grafik perbandingan kapasitas tarik izin fondasi tiang

Berdasarkan tabel 1 dapat dihitung persen perbedaan kapasitas tekan izin dan kapasitas tarik izin tiang pada kedalaman 26 meter dan 30 meter seperti pada tabel 3.

Tabel 3. Perbedaan kapasitas tekan izin dan kapasitas tarik izin fondasi tiang

\begin{tabular}{ccccc}
\hline $\begin{array}{c}\text { Kedalaman } \\
(\mathrm{m})\end{array}$ & $\begin{array}{c}\text { Kapasitas } \\
\text { Tiang }\end{array}$ & $\begin{array}{c}\text { Baja H-Piles } \\
(\mathrm{kN})\end{array}$ & $\begin{array}{c}\text { Beton Persegi } \\
(\mathrm{kN})\end{array}$ & $\begin{array}{c}\text { Perbedaan } \\
(\%)\end{array}$ \\
\hline \multirow{2}{*}{26} & Tekan & 704.58 & 519.02 & 26.34 \\
\cline { 2 - 5 } & Tarik & 465.29 & 384.45 & 17.37 \\
\hline \multirow{2}{*}{30} & Tekan & 943.53 & 695.77 & 26.26 \\
\cline { 2 - 5 } & Tarik & 636.24 & 509.32 & 19.95 \\
\hline
\end{tabular}

Besar penurunan fondasi tiang pancang baja H-Piles pada kedalaman 26 meter dan fondasi tiang pancang beton persegi prestressed pada kedalaman 30 meter dengan analisis secara manual memiliki hasil seperti pada tabel 4.

Tabel 4. Perbandingan hasil analisis penurunan fondasi tiang

\begin{tabular}{cccc}
\hline Jenis Tiang & $\begin{array}{c}\text { Kedalaman } \\
(\mathrm{m})\end{array}$ & $\begin{array}{c}\text { Penurunan } \\
(\mathrm{cm})\end{array}$ & $\begin{array}{c}\text { Perbedaan } \\
(\mathrm{cm})\end{array}$ \\
\cline { 1 - 3 } Baja H-Piles & 26 & 1.07 & \multirow{2}{*}{1.13} \\
\cline { 1 - 3 } Beton Persegi & 30 & 2.20 & \\
\hline
\end{tabular}


Dengan meninjau kapasitas tekan izin fondasi tiang berdasarkan hasil analisis, berikut gambaran perbandingan harga material tiang apabila fondasi tiang pancang baja $H$-Piles digunakan sepanjang 26 meter dan fondasi tiang pancang beton persegi prestressed digunakan sepanjang 30 meter.

Tabel 5. Selisih harga material tiang per meter

\begin{tabular}{ccc}
\hline \multirow{2}{*}{ Uraian } & \multicolumn{2}{c}{ Biaya } \\
\cline { 2 - 3 } & Beton Persegi & Baja H-Piles \\
\hline Harga tiang per meter & Rp. 1.350.000,- & Rp. 1.530.800,- \\
\hline Pelapisan anti karat per meter & - & Rp. $104.000,-$ \\
\hline Total biaya & Rp. 1.350.000,- & Rp. 1.634.800,- \\
\hline Selisih harga & Rp. 284.000,- yaitu sebesar 17.42\% \\
\hline
\end{tabular}

Tabel 6. Selisih total harga material tiang

\begin{tabular}{cclc}
\hline Jenis Tiang & Harga per meter & Panjang Tiang & Harga per tiang \\
\hline Baja H-Piles & Rp. 1.634.800,- & 26 meter & Rp. 42.504.800,- \\
\hline Beton Persegi & Rp. 1.350.000 & 30 meter & Rp. 40.500.000,- \\
\hline & & Selisih & Rp. $2.004 .800,-$ \\
\hline & & Selisih & $4.71 \%$ \\
\cline { 3 - 4 }
\end{tabular}

Catatan: Harga material tiang dan pelapisan fondasi tiang pancang baja H-Piles diambil dari Daftar Harga Satuan Material/Bahan Provinsi DKI Jakarta 2017 dan harga material fondasi tiang pancang beton persegi prestressed diperoleh dari salah satu supplier tiang pancang.

\section{KESIMPULAN}

Dari analisis perhitungan kapasitas tekan, kapasitas tarik dan penurunan fondasi tiang pancang baja $H$-Piles dan fondasi tiang pancang beton persegi prestressed yang telah dilakukan, dapat ditarik kesimpulan sebagai berikut:

1. Dari segi kapasitas, berdasarkan tabel 3 diperoleh kesimpulan bahwa pada kedalaman yang sama, fondasi tiang pancang baja $H$-Piles memiliki kapasitas tekan izin yang lebih besar $26.34 \%$ dan $26.26 \%$ serta kapasitas tarik izin yang lebih besar $17.37 \%$ dan $19.95 \%$ dibandingkan dengan kapasitas fondasi tiang pancang beton persegi prestressed.

2. Berdasarkan tabel 1, diperoleh kesimpulan bahwa kapasitas tekan izin fondasi tiang pancang beton persegi prestressed pada kedalaman 30 meter sebesar $695.77 \mathrm{kN}$ memiliki nilai yang hampir sama dengan kapasitas tekan izin fondasi tiang pancang baja H-Piles pada kedalaman 26 meter sebesar $704.58 \mathrm{kN}$.

3. Berdasarkan tabel 1, diperoleh kesimpulan bahwa kapasitas tarik izin fondasi tiang pancang beton persegi prestressed pada kedalaman 30 meter sebesar $509.32 \mathrm{kN}$ memiliki nilai yang hampir sama dengan kapasitas tarik izin fondasi tiang pancang baja H-Piles pada kedalaman 27 meter sebesar $506.26 \mathrm{kN}$.

4. Dari segi penurunan, berdasarkan tabel 4 diperoleh kesimpulan bahwa pada kedalaman 26 meter penurunan fondasi tiang pancang baja H-Piles sebesar $1.07 \mathrm{~cm}$ memiliki nilai yang lebih kecil $1.13 \mathrm{~cm}$ dibandingkan dengan penurunan fondasi tiang pancang beton prestressed pada kedalaman 30 meter sebesar $2.20 \mathrm{~cm}$.

5. Dari segi biaya, berdasarkan tabel 6 harga material fondasi tiang pancang baja H-Piles memiliki biaya yang lebih besar sebanyak Rp. 2.004.800,- atau 4.71\% dibandingkan dengan harga material fondasi tiang pancang beton persegi prestressed.

6. Perbedaan biaya material dapat menjadi salah satu alasan tiang pancang beton persegi prestressed lebih banyak digemari dibandingkan dengan tiang pancang baja H-Piles di Indonesia. Di Amerika Serikat fondasi tiang baja cenderung lebih diminati karena harganya yang lebih terjangkau dan kekuatannya yang lebih tinggi. Salah satu faktor yang mempengaruhi harga material adalah ketersediaan sumber daya alam (SDA) dan sumber daya manusia (SDM). Salah satu penyebab Amerika Serikat cenderung lebih mudah memperoleh baja daripada beton adalah karena ketersediaan sumber daya alam untuk bajanya yang mendukung. Dari sisi sumber daya manusia, produksi baja cenderung menggunakan mesin dengan lebih sedikit tenaga kerja manusia dibandingkan dengan pembuatan beton sehingga dengan upah pekerja yang terus menerus naik, tidak menutup kemungkinan bahwa biaya produksi baja akan lebih murah dibandingkan biaya produksi beton. 


\section{DAFTAR PUSTAKA}

Badan Standarisasi Nasional. (2017). Standar Nasional Indonesia 8460:2017 Persyaratan Perancangan Geoteknik. Badan Standarisasi Nasional, Jakarta.

Bowles, J.E. (1997). Foundation Analysis and Design (Fifth Edition). McGraw-Hill Companies Inc, Singapore.

Bowles, J.E. (1997). Analisis dan Desain Pondasi (Edisi Keempat Jilid 1). Erlangga, Jakarta.

Coduto, D. P., Kitch, W. A., dan Yeung, M. R. (2016). Foundation Design: Principles and Practices (Third Edition). Pearson, California.

Deep Foundation Research Institute. (2013). Manual Pondasi Tiang Edisi 4. Geotechnical Engineering Center, Bandung.

Pandu Bangun Persada Nusantara. (2017). "Daftar Harga Satuan Material/Bahan Provinsi DKI Jakarta". Harga Satuan Bahan Bangunan Konstruksi dan Interior, Edisi 36 Tahun XXIII, 250.

Salgado, R. (2008). The Engineering of Foundations. McGraw-Hill, New York.

Sardjono, H.S. (1988). Pondasi Tiang Pancang Jilid 1. Sinar Wijaya, Surabaya. 